\title{
Dynamics of the Nature and Value of Urban Agriculture in Arusha City, Tanzania: The Case of Daraja Mbili and Lemala Wards
}

\author{
Pastory Salvatory Thomas ${ }^{1 *}$, Wilbard Jackson Kombe ${ }^{2}$, Aldo Lupala ${ }^{3}$ \\ ${ }^{1}$ Department of Crop Science and Horticulture, Faculty of Agriculture, Sokoine University of Agriculture, Morogoro, Tanzania \\ ${ }^{2}$ Institute of Human Settlements Studies, Ardhi University, Dares Salaam, Tanzania \\ ${ }^{3}$ Department of Urban and Regional Planning, School of Spatial Planning and Social Sciences, Ardhi University, Dar es Salaam, \\ Tanzania \\ Email: *pastory.thomas@sua.ac.tz, kombewilbard18@gmail.com, aldo.lupala@aru.ac.tz
}

How to cite this paper: Thomas, P. S., Kombe, W. J., \& Lupala, A. (2021). Dynamics of the Nature and Value of Urban Agriculture in Arusha City, Tanzania: The Case of Daraja Mbili and Lemala Wards. Current Urban Studies, 9, 481-501.

https://doi.org/10.4236/cus.2021.93030

Received: August 7, 2021

Accepted: September 3, 2021

Published: September 6, 2021

Copyright $\odot 2021$ by author(s) and Scientific Research Publishing Inc. This work is licensed under the Creative Commons Attribution International License (CC BY 4.0).

http://creativecommons.org/licenses/by/4.0/ (c) (i) Open Access

\begin{abstract}
In the near future, urban agriculture will not be the same as it was in the past or as it is at present. The different forms and context at which agricultural activities take place can have different effects on the value of urban agriculture. Information about the actual ideal place where urban agriculture has to be done and about the exact of value of urban agriculture is implicit. This study examines the factors that characterise the change of the nature and value of urban agriculture in Arusha as one of the rapidly urbanizing cities in Tanzania. It uses two case study areas that were purposefully selected from Arusha City, namely the wards of Daraja Mbili and Lemala. A total of 60 respondents participated in depth interviews. The study reveals that limited access to ideal areas for doing urban agriculture has made some farmers to acquire small portions of land in unlawful areas for that purpose. Hence, the livestock kept are limited in numbers and crops grown are those that take a short time to grow but with less ability to suffice the food needs of the farmers and urban residents. It also reveals that the majority farmers whose land is somehow secured to meet their food and income needs through agriculture. However, uncontrolled agricultural practices have on the one hand accelerated environmental degradation and pollution, its roles on supporting livelihoods of needy farmers cannot be underrated. The study argues that urban agriculture cannot take place in the absence of adequate access to agricultural land by the farmers. It cannot also take place in the weak institutional framework that can guide its operations without jeopardising other urban land uses.
\end{abstract}

\section{Keywords}

Dynamics, Nature, Value, Urban Agriculture, Arusha City, Daraja Mbili and 


\section{Introduction}

Before the 1980s, the population in rural areas in sub-Saharan African countries was larger than that in urban areas. At the time, most of agricultural studies focused on rural agriculture because the rural areas were where most of the people lived (UN-Habitat, 2008; Lau, 2013). The studies aimed at finding solutions to scarcity of food and unemployment through the production of commercial and exportable crops (UN-Habitat, 2008; Wakuru, 2008; Mireri, 2013). As time passed, birth rates increased and rural urban-migration increased as well owing to economic hardships and the availability of employment opportunities in urban areas. Thus, the urban population grew.

In 2008, the world urban population outnumbered the rural world population. Yet, there is no convincing evidence indicating that the reverse will occur in the near future (World Bank, 2013). Rather, it is projected that the urban population will increase from 3.3 billion people in 2007 to 6.4 billion by 2050 (ibid). The statistical projection by the World Bank implies that more food and employment opportunities are needed in urban areas. Among other reasons, the people migrating to urban areas assumed that employment and other opportunities were plenty in urban areas compared to rural ones. However, their assumption was wrong. In the context of developing countries, cities urbanize in poverty situations (Kombe, 2005; Barofsky et al., 2016; Mugisa et al., 2017). Such urbanization is associated with food insecurity, limited employment opportunities and poor housing and infrastructure services associated with the penurious life of urban people (Kombe, 2005; UN-Habitat, 2008; World Bank, 2013).

As cities in developing countries urbanize as a result of overpopulation, need for food increases (Badami \& Ramankutty, 2015; Tefft et al., 2017). Yet, former agricultural land in the urban areas has continued to shrink in size owing to rapid urbanization (Odudu \& Omirin, 2012; McLees, 2011). The rapid and unplanned urban growth for housing in Ibadan has limited farmers' access to land for agricultural purposes (Wahab et al., 2018). In Ibadan, food insecure and unemployed people would have wished to practise urban agriculture, but access to land within the urban areas was limited (ibid). However, part of the food consumed in urban areas can be imported from rural areas, but not every person in urban areas can afford the price at which food is sold (Wakuru, 2008; Mkwela, 2013). For example, food insecure people in Harare limit their food portions, reduce the number of meals, sell some of their assets to get money for buying food and eat less preferable food (Crush \& Frayne, 2011). All these are considered coping strategies to food scarcity in urban areas.

The practise of urban agriculture has both negative and positive effects on the urban environment (Peters, 2010; Hallett et al., 2016). On the positive side, ur- 
ban agriculture cools and greens urban environment, utilizes urban decomposable waste, intercepts soil erosion and minimizes land degradation (Hallett et al., 2016). Uncontrolled urban agricultural activities are said to contribute to soil erosion, contamination of ground water, loss of fauna and flora, and the pollution of urban environment (Peters, 2010). The environmental benefits and problems of urban agriculture are not typical; they are specific to a given location. The benefits of urban agriculture are sometimes misconceived because they are not analysed in relation to their specific settings (Sabiiti et al., 2014; Mugisa et al., 2017).

One of the challenges city authorities face is attempting to ensure that farmers' livelihoods obtained from urban agriculture do not compromise human health and environmental protection initiatives (Peters, 2010; Sabiiti et al., 2014). It was said that a similar situation existed in urban areas in Tanzania (Mkwela, 2013). In the country, the way urban agriculture is practised, the areas where it is practised, the benefits it provides to farmers and other urban residents, and the effects it has on the urban environment are not similar in all urban areas owing to the dynamism and the extent of urbanisation (Victor et al., 2018).

Rapid urbanization of cities in Sub-Sahara Africa influences the constant change of urban land uses. Due to urbanization in Arusha city, agriculture is one of the urban land use that keep on changing due to burgeoning of non-agricultural land uses such as housing, infrastructure, social services and commercial premises. Despite these general factors, agriculture still exists in uncertain situation in urban areas. With ongoing urbanization, the types of agricultural activities, their locations, size of the land and ways of accessing it will also vary. However, recently there is limited knowledge on how such changes take place and challenge the value related to food and income of the farmers as well as value linked to environment.

\subsection{Discourses on the Diverse Nature and Value of Urban Agriculture}

The growing of crops and the keeping of livestock are what most researchers call urban agriculture (Schmidt, 2012; Mireri, 2013). The processing, storing and distribution of agricultural products are also related to urban agriculture (Game \& Primus, 2015). That is the case because, beyond mere production of agricultural products, the products produced have to get to the final consumer through marketing (Dorward et al, 2013). Urban agriculture also includes access to land and management of agricultural waste in the urban areas (ibid). It is from that perspective that, Mougeot (2000) argues that the places where urban agriculture is practised and the benefits it offers are typified differently.

In China, some people recycle agricultural residues and decomposable wastes into organic manure (Lau, 2013). They are not real farmers, but they are employed in that sector linked to urban agriculture (ibid). In areas where the waste from urban agriculture cannot easily be turned into organic manure, agriculture 
is blamed for generating an unpleasant smell, especially when the waste is not properly managed (Sabiiti et al., 2014). However, in Beijing, agricultural practices face great pressure from the scarcity of land caused by urbanization, its benefits in terms of job creation and food provision are recognized without downplaying environmental protection (Yang et al., 2016). In Kampala City, agricultural activities done away from farmers' residences have substantial a contribution to their income and food. Nevertheless, they are among the activities that contribute to land degradation (Sabiiti et al., 2014). The agricultural activities done within built-up areas might not lead to severe land degradation, but they may produce unpleasant odors and a disruptive noise (Aubry et al., 2012; Dorward et al., 2013).

Despite the hurdles urban farmers face in accessing land, water and technical support, they still engage in agriculture (Victor et al., 2018). In Kampala city, the number of urban farmers increases at the rate of two percent per year, but the size of agricultural plots decrease (Sabiiti et al., 2014). The existing farmers and those who join the industry for the first time in Kinondoni (Tanzania) are more than those who quit it (Victor et al., 2018). However little it may be, the amount of income and food farmers get enable them to lessen unemployment and food shortage problems (ibid). However there is inadequate up to date information for determining whether the value of urban agriculture in terms of food and income is sufficient or not especially at an increasing rate of urbanization. The increase or decrease in the number of those who engage in agricultural activities has a direct link with the size of their farming land and the way agricultural land is accessed (Namwata et al., 2015; Quan, 2015). In addition, it has a relation to the benefits of urban agriculture and the extent to which urban agriculture is regulated or tolerated (Smit, 2016; Kiduanga \& Shomari, 2017). As a city urbanises, land for non-agricultural uses is given more consideration than land for agricultural uses (McLees, 2011). This situation makes farmers struggle on their own to find a place where they can undertake their agricultural activities (Namwata et al., 2015; Sarker et al., 2019). They hardly succeed and as the results they invade restricted public land (Sarker et al., 2019). In turn, authorities of respective cities formulate regulations and bylaws for regulating the conduct of urban agriculture.

\subsection{Legal Aspects of Urban Agriculture}

Urban authorities respond to uncontrolled urban agriculture by formulating rigorous bylaws and regulations which are sometimes seen as obstacles to the prosperity of urban agriculture (Kiduanga \& Shomari, 2017). Through its laws and policy, Tanzania has recently recognized the practises of urban agriculture in the Housing and Human Settlements Development Policy of 2000 and Urban Planning Act of 2007 (URT, 2000; URT, 2007; Schmidt, 2012). With such recognition, one might be interested in establishing whether or not agricultural land use is incorporated in the urban land use planning practices. Dar es Salaam City 
Council does not prohibit farmers from practising agriculture in a way that do not jeopardize other non-agricultural land uses such as housing and road infrastructure (Kiduanga \& Shomari, 2017). When prohibitive laws are enforced strictly, the numbers of people who previously practised uncontrolled agriculture fall (Hamisi, 2012). Constitutionally, the legal provisions pertaining to urban agriculture and the environmental protection are always neutral and valid. However, there is no way farmers can think that they are fair to them, especially when they seem to block activities leading to their food and income (Schmidt, 2012; Mkwela, 2013).

Various issues emerge from the background to the study and review of the literature more generally. The ways of accessing agricultural land, ideal location for agricultural activities and reasons for engaging in agriculture seem to differ. Moreover, the information of urban agriculture from one city can hardly be generalised to another cities because each city is administered differently. In addition, the way population behaves and the way land for agriculture is accessed also differs. The way urban agriculture is supported, tolerated or discouraged also differs from one place to another. All these have both negative or positive effects on agriculture and its prosperity. The knowledge gap is on how such circumstances favour or hinder the practices of urban agriculture and its associated benefits. Therefore, this study examines the nature and value of urban agriculture in Arusha City, in particular in the wards Daraja Mbili and Lemala.

\section{The Conceptual Framework}

Conceptualising of the variables which emanated from the literature helps in figuring and interlinking them in the conceptual framework of the study which is connected with research issue. Variables embedded in the conceptual framework delimit the scope of the study and guided researchers to focus about pertinent issues of the study. The conceptual framework in Figure 1 shows concepts nature and value as well as their imbedded sub-variables.

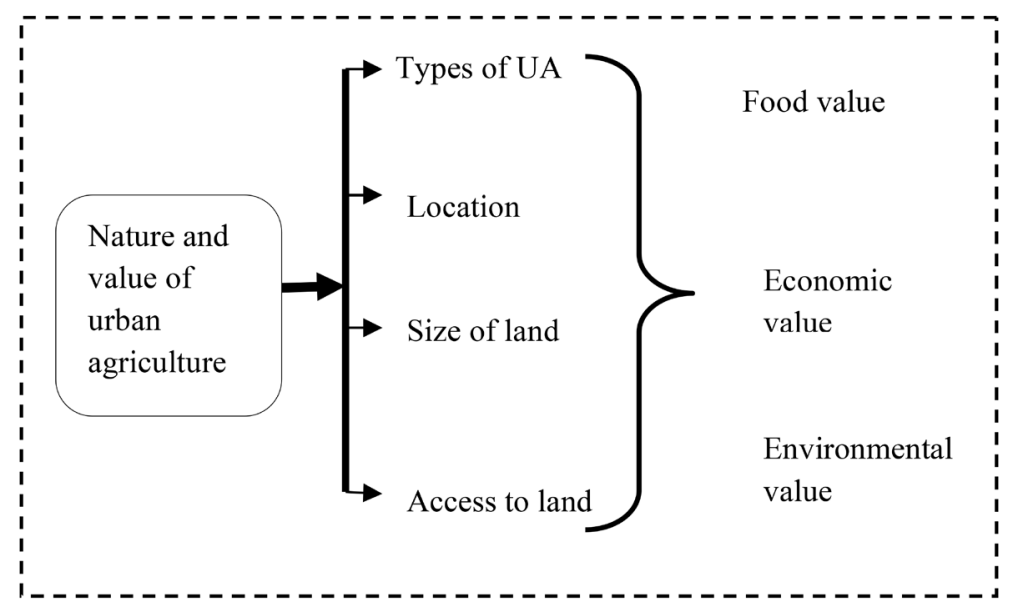

Source: Author's own construct, 2020.

Figure 1. Conceptual framework. 
The variable of nature comprises the sub-variable types, location, size and access which emanated from the literature review. The types of urban agriculture can be either crop cultivation, livestock keeping or floriculture. The location can be within the plot of residents or away from it. The size of the land can be medium or small in meter or acre measurements. The way land is accessed also can determine the nature of urban agriculture. Type involves livestock kept or crops grown by farmers. All these sub-variables characterize the problems and the basis at which nature of urban agriculture is examined. The value provided by urban agriculture includes food, income and environmental value, but it varies from one urban area to another and from one farmer to another. One of the controversial debates is about the value of urban agriculture having a worth impact to income and food security of farmers and other urban poor as well as conserving or protecting the environment. The data was collected, analysed and discussed based on the variables of the study which mirrored the objective of the study.

\section{Methodology}

\subsection{Description of the Study Area}

Arusha city is located in the Northern side of Tanzania. The Arusha city is found in the Southern side of Mount Meru slopes between 1160 and 1400 meters above the sea level. ${ }^{1}$ The city has a small total area of 208 square Kilometers forming only 0.6 per cent out of 34,526 square kilometers of Arusha region (Hamisi, 2012; ACCMPDR, 2015). It had a population size of 416,442 in 2012 (ACCMPDR, 2015). This population has been rapidly increasing to an extent that it is estimated to reach 1.48 million people by 2035 (ibid). A population increase in the fixed size of land, coupled with increasing socioeconomic activities resulted into increased needs for land for housing, commercial, other non-agricultural uses and agriculture. ${ }^{2}$ In turn, the rapid urbanization coupled with the rapidly increasing population and poverty has led to an increased demand for food and limited employment opportunities. People formally and informally opted to activities that could provide the means of survival including urban agriculture. The study was conducted in Daraja Mbili and Lemala as they represent the rest twenty three wards of the city. The wards have more active farms and agricultural land is intermingled with housing, reserves of infrastructure facilities and other protected public land.

\subsection{Research Design, Data Collection and Analysis Technique}

Given the research question which was to examine the nature and value of urban agriculture in Arusha City within the wards of Daraja Mbili and Lemala, this study adopted a mixed research design. Some of the research questions needed brief and detailed response which could provide both quantitative and qualita-

${ }^{1}$ https://www.arushacc.go.tz/.

${ }^{2}$ Interview with City Urban Planner, September, 2019. 
tive data. Thus, the design was adopted to minimise the weakness which might have arisen from using one method. Respondents were given ample time to narrate what they knew about the questions. In addition, a study deployed a casestudy strategy to get a deeper understanding of the information provided by respondents in two separate wards. This strategy was also adopted because circumstances in which urban agriculture was practised were contemporary and specific in each ward. Thus, knowledge embedded in this study could be fully understood through having descriptive and explanatory data. As such, the data were collected using brief (structured) and in-depth (unstructured) interviews, as well as observation.

A total of 60 respondents were interviewed, including 40 urban farmers, 5 agricultural officers, 4 urban planners, 3 environmental officers, 4 subward leaders, 2 famous ward elders an one officer from environmental organization and agricultural association. Forty farmers from Daraja Mbili and Lemala were interviewed, whereby twenty farmers were purposefully selected from each ward. In all wards, $65 \%(n=40)$ of farmers were male while $35 \%(n=40)$ were female. Most of female were housewives who completely engaged in domestic activities as well as caring for children. Seventy per cent of the farmers had primary education, 20\% ( $n=40)$ had ordinary secondary education and 5\% $(n=40)$ had advanced secondary education. The age of all farmers ranged from 18 to 60 years. Excluding farmers, twelve respondents were male and eight were female. Except for famous ward elders who had primary education, other officials had more than advanced secondary education as well as college and university education.

Urban planners, agricultural and environmental officers, sub-ward leaders, famous elders and representatives of agricultural and environmental organizations were interviewed. All respondents were purposively selected because they were the ones who provided sufficient information on the nature and value of urban agriculture. The data were assigned codes prior to analysis. The coded data were analyzed on the basis of their content to understand the meaning contained in them. Moreover, data with implicit information were analysed thematically so as to have flexible interpretations of the findings. Numeric data were analysed by using the Statistical Package for Social Science Studies (SPSS) to generate information which was expressed in percentages in tables.

The questions for the interview included, but not limited to, where do you/ farmers carry out urban agricultural related activities? Why do you/farmers practise agriculture in those areas? Why you have opted to grow these crops or kept these livestock? How do you/farmers access land you/they are conducting urban agriculture? What challenge do you/farmers face in accessing agricultural land? In either of the way you have accessed land, is the land size sufficient to meet your needs as a farmer? If yes: how? If no: why not? Other question included why are you/farmers involved in agricultural activities? Could you/farmers survive without engaging in urban agricultural activities? What adverse and desirable effects of agriculture on environment? What are challenges of the value of 
urban agriculture and how do they affect it?

\section{Results}

\subsection{The Nature of Urban Agriculture}

The nature of urban agriculture includes such variables as type, location, size and the means through which the urban farmers access agricultural land.

\section{Types}

The study has revealed that the farmers engaged in both crop cultivation and livestock keeping in different context as types of urban agricultural activities (see Table 1).

In both wards, many people practised the crop cultivation and livestock keeping because the crops residues and peels used to feed some of the livestock while animal droppings were used as manure. ${ }^{3}$ They did so to avoid the loss or mishap that could happen to one type of agricultural activity. The number of livestock kept by the farmers differed from one farmer to another. Some farmers kept only 1000 chickens while others kept 50 chicken, 20 duck or two cattle. Others grow vegetable in an quarter of an acre while others grew two to five three beds of amaranth or spinach of one by four meter size.

Unlike in Daraja Mbili, in Lemala permanent crops such banana, avocado, guava and orange were grown because in the area, most farmers' land has secured tenure. In both wards, farmers grew vegetable such as sweet potato leaves, leeks, eggplant, black nightshade, beans, amaranth, maize, sweet pepper and celery. However, vegetable were mostly grown by the farmers because they have short growing cycles, they can be grown on land with less security of tenure and their cultivation on a small piece of land require a small capital investment. In both wards, crops such as lemon grass, lemon and cherry pepper were grown by a small number of farmers because they were consumed in small quantities. In both wards, the farmers who were facing a shortage of land grew vegetable crops in containers such pots and sacks and kept limited number of livestock under zero grazing systems. The number of such farmers was small because agricultural land was not easily accessible, even those who practised zero grassing wished

Table 1. Crop cultivation and livestock keeping.

\begin{tabular}{ccc}
\hline Agricultural activities & Daraja Mbili & Lemala \\
\hline Crop cultivation & $40.0 \%$ & $45.0 \%$ \\
Livestock keeping & $10.0 \%$ & $5.0 \%$ \\
Both crops cultivation and livestock keeping & $40.0 \%$ & $55.0 \%$ \\
Commercial floriculture & $10.0 \%$ & $5.0 \%$ \\
Total & $100.0 \%$ & $100.0 \%$ \\
\hline
\end{tabular}

Source: Survey data, 2019.

${ }^{3}$ Interview with a farmer in Lemala, September, 2019. 
they could kept more livestock but there was no more land to support them. A few number of beehives hung from trees along the valleys in Kolongoni area where human activities were not common were observed. Ornamental trees, shrubs and flowers were grown in small quantities by farmers for commercial purposes. In Daraja Mbili, ornamental crops were grown at the road junction along Jamhuri and Darajani sub-wards. Moreover, vegetable gardens were found along Themi and Naura rivers. Moreover, fodder grasses for feeding cattle were grown along the slope of Engra hill and along the banks of Themi River within Lemala ward. The livestock kept by farmers in both wards were chickens, cattle, pigs, goats, ducks and sheep in order of preference.

\section{The location of agricultural activities}

Farmers in Daraja Mbili and Lemala reported to practise agricultural activities within their residences (on-plot), away from the residencies (off-plot) and in both locations as in Table 2 shows.

The study revealed that on-plot urban agriculture was practised by farmers whose obtained land through either customary or statutory rights. Moreover, farmers who cultivated crops away from their residences (on the land they bought from other people) practised both on and off plot agriculture. Keeping livestock under zero grassing in an off-plot location was said to be impossible, since it required areas where one could build permanent agricultural irrigation infrastructure and structures for keeping livestock in an enclosed area. Those who practised agricultural activities within the residence, they did so to minimize theft and to care their crops and livestock more closely. In addition, the land which on-plot agricultural activities were done was legally acquired. Hence, the people grew permanent crops and constructed permanent sheds for their livestock. The researchers also observed on-plot and off-plot agricultural activities in both wards as Figure 2 shows. The farmers reported that on off-plot agriculture, crops were grown along river valleys because areas were fertile and productive and retained the water for irrigation from June to October which is a dry period. They temporarily grew crops without fertilizing the soil and did not think that other areas could be as fertile as their areas. The farmers who practised agriculture on the plots located away from their residence did so along the valleys and the banks of Rivers Themi and Naura. They squatted or invaded the land. Squatting of public land for doing urban agriculture was also done below power lines and road

Table 2. Areas where urban agriculture is practised.

\begin{tabular}{ccc}
\hline Location & Daraja Mbili & Lemala \\
\hline Within residences & $40.0 \%$ & $80.0 \%$ \\
Away from residences & $30.0 \%$ & $20.0 \%$ \\
Within and away from residences & $30.0 \%$ & 0 \\
Total & $100.0 \%$ & $100 \%$ \\
\hline
\end{tabular}

Source: Survey data, 2019. 
reserves (see Figure 2).

In Lemala, urban agriculture was also practised differently on land located away from farmers' residences as Figure 3 shows.

Furthermore, it was substantiated by a sub-ward leader from Daraja Mbili that farmers who practise off-plot agriculture on restricted land knew very well that they were using restricted land, but they did so because no another place they could get land for growing vegetables. Four urban planners and four environmental officers did not consider the practise of agriculture on the land found in catchments areas and along road and railway reserves as an ideal practice because the land was not reserved for urban agriculture. However, environmental officers had no problems with the agricultural activities which involved growing of shrubs and fodder grass and which complimented environmental conservation activities. On the other hand, the urban planners reported that they could have succeeded in protecting land along the public infrastructure from being used for agricultural activities, but they were busy with other activities pertaining to urban development control and land planning in new areas for non agricultural development purposes. Hence, they had limited time to patrol every area

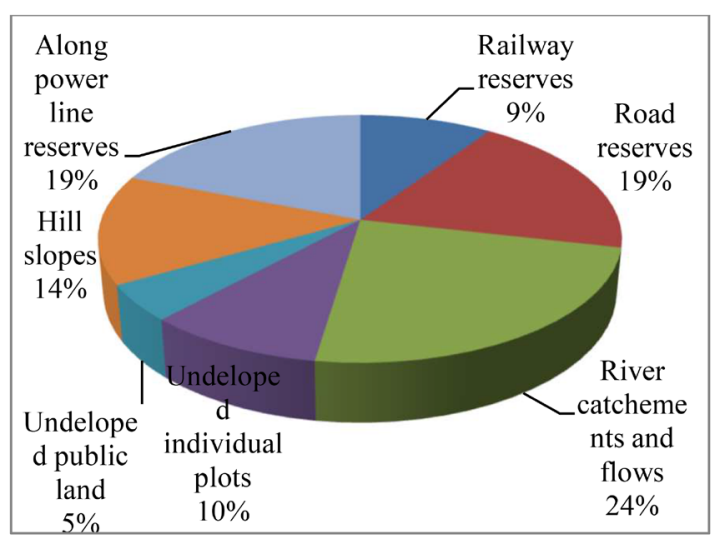

Source: Survey data, 2019.

Figure 2. Places where off-plot urban agriculture is practised in Daraja Mbili.

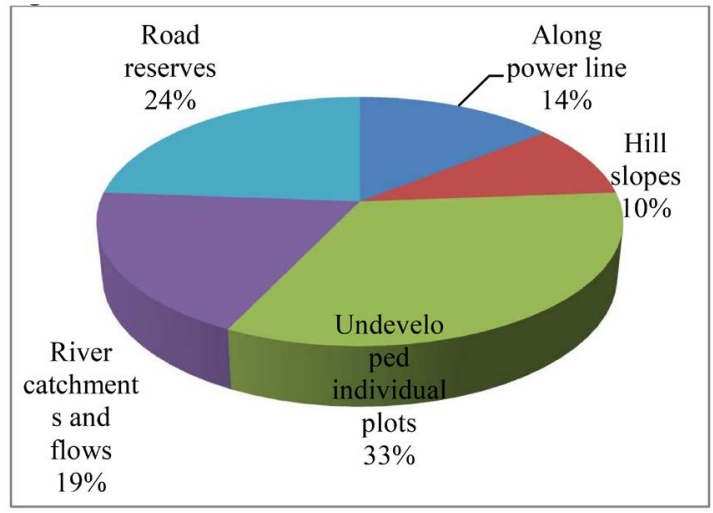

Source: Survey data, 2019.

Figure 3. Places where off-plot urban agriculture is practised in Lemala. 
in which people practised urban agriculture on public land. The environmental officers reported that urban farmers undertook agricultural activities in such areas late in the evening when they could not easily be seen. Urban agricultural activities away from residence within Daraja Mbili are shown in Figure 4.

Urban agricultural activities within residence in Lemala are shown in Figure 5.

\section{The size of agricultural land}

The study revealed that the size of agricultural land in both Daraja Mbili and Lemala determined the types of crops grown and the types of the livestock kept. However, the plots varied in terms size, mostly were smaller than $2000 \mathrm{~m}^{2}$ (75\% in both wards). The farmers who occupied agricultural land of that size wished that they had more land. They thought that the small size of the land prevented them from advancing their farming activities. The rest $25 \%$ in both wards had agricultural land which exceeded $2000 \mathrm{~m}^{2}$, most of which had been inherited from their parents. Of all the farmers who were interviewed in Daraja Mbili and

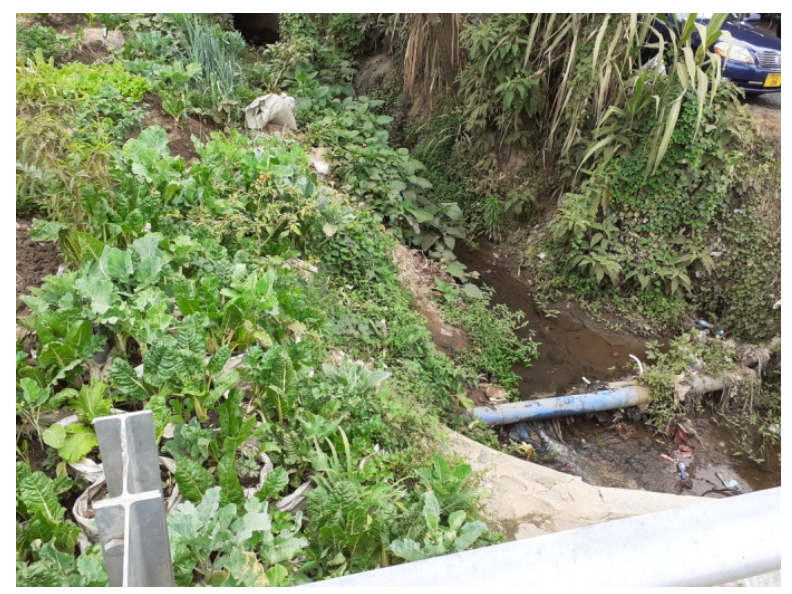

Source: Survey data, 2019.

Figure 4. Off-plot urban agriculture in Daraja Mbili.

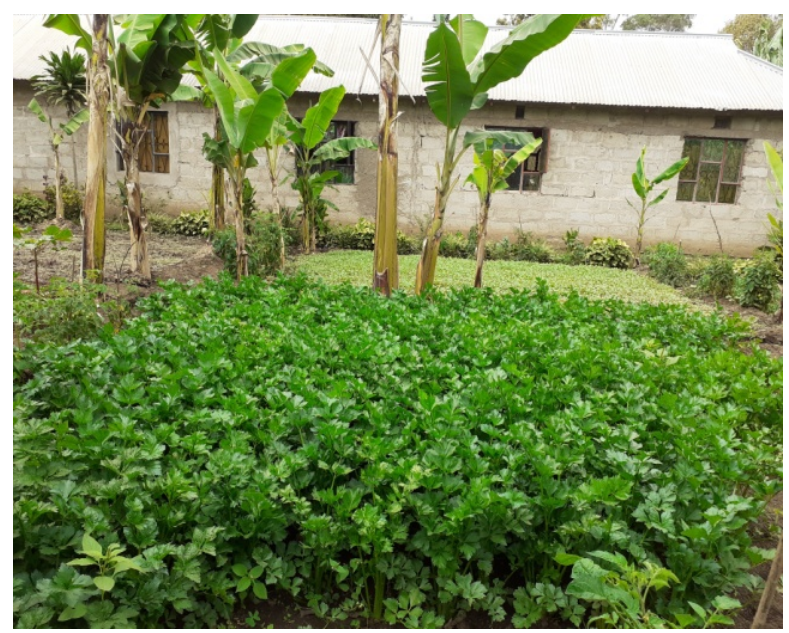

Source: Survey data, 2019.

Figure 5. On-plot urban agriculture in Lemala. 
Lemala, about $70 \%(n=20)$ in each ward reported that the land they occupied did not meet their objectives, while $30 \%$ pointed out that it met their objective to some extent because they knew how difficult it was to get large piece of land in the city.

\section{Access to agricultural land}

The findings showed the relationship between the way urban agricultural land was accessed and the size of the land. The land was mainly acquired through inheritance and squatting. There was also land which was bought and leased as Table 3 shows.

The farmers who carried out agricultural activities on land whose size was less than $1000 \mathrm{~m}^{2}$ got land mostly through squatting, which was considered as an illegal ways of accessing agricultural land. The land accessed through inheritance was slightly bigger than that which was obtained through squatting.

In Lemala, there was also the relationship between ways of accessing agricultural land and the size of land as Table 4 shows.

It was also reported by the chief agricultural officers of Arusha City that the continues urbanizing, and that land was needed for other non-agricultural uses, a situation that did not allow a farmer to occupy as much land as he/she wanted.

Table 3. Access to and the size of land in Daraja Mbili.

\begin{tabular}{|c|c|c|c|c|c|c|}
\hline \multirow{2}{*}{$\begin{array}{l}\text { Access to agricultural } \\
\text { land }\end{array}$} & \multicolumn{5}{|c|}{ Size of agricultural land $(n=20)$} & \multirow[b]{2}{*}{ Total } \\
\hline & $\begin{array}{c}<1000 \\
\mathrm{~m}^{2}\end{array}$ & $\begin{array}{c}1001-2000 \\
\mathrm{~m}^{2}\end{array}$ & $\begin{array}{c}2001 \mathrm{~m}^{2}-1 \\
\text { acre }\end{array}$ & $\begin{array}{l}1-2 \\
\text { acres }\end{array}$ & $\begin{array}{c}>2 \\
\text { acres }\end{array}$ & \\
\hline Inheritance & - & $25.0 \%$ & $10.0 \%$ & $10.0 \%$ & - & $45.0 \%$ \\
\hline Buying & - & $15 \%$ & - & - & - & $15.0 \%$ \\
\hline Squat & $25.0 \%$ & - & $5.0 \%$ & - & - & $30.0 \%$ \\
\hline $\begin{array}{l}\text { Temporary leasing } \\
\text { someone's land }\end{array}$ & - & $5.0 \%$ & $5.0 \%$ & - & - & $10.0 \%$ \\
\hline Total & $25.0 \%$ & $45.0 \%$ & $20.0 \%$ & $10.0 \%$ & - & $100.0 \%$ \\
\hline
\end{tabular}

Source: Survey data, 2019.

Table 4. Access to and the size of land in Lemala

\begin{tabular}{cccccc}
\hline \multirow{2}{*}{$\begin{array}{c}\text { Access to } \\
\text { agricultural land }\end{array}$} & \multicolumn{4}{c}{ Size of agricultural land (n=20) } & \multirow{2}{*}{ Total } \\
\cline { 2 - 6 } & $<1000 \mathrm{~m}^{2}$ & $1001-2000 \mathrm{~m}^{2}$ & $2001-1$ acre & 1 to 2 acre & \\
\hline Inheriting & $5.0 \%$ & $15.0 \%$ & $20.0 \%$ & $10.0 \%$ & $55.0 \%$ \\
Buying & - & $5.0 \%$ & - & - & $5.0 \%$ \\
Squatting & $25.0 \%$ & $5.0 \%$ & - & $5.0 \%$ & $35.0 \%$ \\
Leasing & $5.0 \%$ & - & - & - & $5.0 \%$ \\
Total & $40.0 \%$ & $25.0 \%$ & $20.0 \%$ & $\mathbf{1 5 . 0 \%}$ & $100.0 \%$ \\
\hline
\end{tabular}

Source: Survey data, 2019. 
Moreover, limited access to agricultural land was one of the main concerns reported by the farmers. Land inheritance was reported to be favouring only few farmers. Although land squatting was illegal, it was the main way of accessing land because of the laxity and inability of the city authority to ensure equitable access to agricultural land. The laxity in question was perpetuated by limited staff and financial resources with which could be used to hire land rangers. ${ }^{4}$ Buying land for agricultural purposes was not common because the land in all wards within the city, including the wards covered by this was sold informally at an exorbitant price. A plot on which a $4 \mathrm{~m}$ by $4 \mathrm{~m}$ room can be built cost two to three million Tanzanian shillings. ${ }^{5}$ Majority of the farmers could not afford it. However, a few people, who had somewhat bigger plots for residential purpose, were not restricted from growing vegetables in small gardens or keeping livestock, depending on the carrying capacity of the land. ${ }^{6}$

\subsection{The Value of Urban Agriculture}

The value of urban agriculture reported by the farmers included food, income and environmental value. The value differed between farmers, consumers and those who distributed agricultural inputs and outputs. It also differed from one locality to another within the study areas depending on the way land was accessed and used.

\section{Food and income}

Out of the 20 farmers interviewed in Daraja Mbili and Lemala, more than 80\% practised agriculture to get food and income, and about $20 \%$ practised it only to get income. With regard to income, they were involved in agriculture because they could somehow afford to purchase the food they did not grow by themselves after selling agricultural products. On the other hand; the farmers had different opinions regarding the possibility that they could produce food for consumption and income generation (see Table 5).

The farmers reported that the food produced could enable them to meet their food needs, only to some extent. The food crops grown such as vegetables, spices

Table 5. The potential of urban agriculture to meet food needs.

\begin{tabular}{ccc}
\hline $\begin{array}{c}\text { Possibility of urban agriculture } \\
\text { to meet food needs. }\end{array}$ & $\begin{array}{c}\text { Daraja Mbili } \\
(\mathbf{n}=\mathbf{2 0})\end{array}$ & $\begin{array}{c}\text { Lemala } \\
(\mathbf{n}=\mathbf{2 0})\end{array}$ \\
\hline Possible & $5.0 \%$ & $15.0 \%$ \\
Somewhat possible & $55.0 \%$ & $75.0 \%$ \\
Not possible & $45.0 \%$ & $10.0 \%$ \\
Total & $\mathbf{1 0 0 . 0 \%}$ & 100.0 \\
\hline
\end{tabular}

Source: Survey data, 2019.

${ }^{4}$ Interview with a senior urban planner at ACC, September, 2019.

${ }^{5}$ Interview with a farmer and famous elder in Lemala, September, 2019.

${ }^{6}$ Interview with a famous elder in Lemala, September, 2019. 
and fruits were not consumed as a complete dietary food. They needed to be complemented with other cereal and staple foods. They reported that limited access to land had made them practise agriculture on the un-authorized and small land sized land, which limited the amount and types of crops they could grow of the livestock they could keep.

The farmers also reported that urban agriculture could not provide enough for food and income generation. That was because the income earned was not sufficient enough for them to meet all their income needs, they relied on the little income generated to supplement the income generated from other sources. On the one hand, some farmers who kept livestock in large quantities sold livestock products and got money for clothing, health service' charges and housing. Farmers who produced more food crops also sold the surplus. On the other hand, the ward agricultural officers of Daraja Mbili and Lemala pointed out that those who engaged in urban agriculture were somewhat food secure than those who had no alternative means of meeting their food needs. One of the farmers report that:

I would be leading miserable life if I was not engaging in urban agriculture. Although, what I get from agriculture does not enable me to meet all my food and income needs, I cannot complain.?

On the other hand, the urban planners did not really see the monetary value of urban agriculture arguing that even if agriculture did not exist in the city, still the city would prosper.

\section{Environment}

The farmers were of the opinion that agriculture preserved the environment and controlled soil erosion. The fodder grass grown on the slope of the Engra hill in Lemala was consumed by their livestock. The grass partly minimized soil erosion when it rained. ${ }^{8}$ Moreover, it was the farmers who owned land and kept livestock who used the crop residues and peels as organic manure to fertilize their gardens. On the other hand, the city and ward environmental officers regarded uncontrolled agriculture as one of the agents of soil erosion along the Rivers Themi and Naura. They considered uncontrolled agricultural activities as a source of environmental pollution in the habitable areas in the ward. The city planners and environmental officers acknowledged that the growing of non-food crops such as shed-trees, shrubs, flowers and turf grass made the built-up areas with the Central Business District more green and attractive. However, they were averse to the uncontrolled urban agricultural activities done along the catchment areas of the rivers Themi and Naura because they triggered environmental land degradation. The agricultural officer at Daraja Mbili mentioned that greenhouse, mushroom farming, indoor livestock keeping and the growing of cover crops rarely degrade the environment. The agricultural officer of Lemala reported that the improper and poorly managed urban agriculture practised in the Kolongoni sub-ward had loosen the soil along the natural flow of the River Themi. It was

${ }^{7}$ Interview with a farmer at Daraja Mbili, September, 2019.

${ }^{8}$ Interview with agriculture officer at Lemala, October, 2019. 
also reported by the sub-ward leaders that the eroded materials blocked water culverts in the ward. This situation made agricultural activities to be considered as a barrier to environmental protection and conservation. Strict bylaws were introduced by the city authorities to restrict agricultural activities in the public restricted land. However, on the other hand, bad smell within the habitable place of Daraja Mbili was also reported as a nuisance to people.

Limited access to land and small size of land made farmers to cultivate crops in unauthorized areas. Small size of land (less than $1000 \mathrm{~m}^{2}$ ) limited the types of crops grown by farmers. Farmers were uncertain about farming on unauthorised land hence; they grew only vegetables which could be harvested in few weeks from planting time. These were among the factors which reduced amount of food produced and income earned by the farmers. Livestock could hardly be kept on the plot within farmers' residences by farmers with limited access to land. Respondents had opinion that when agricultural land use hurdles could be solved, the value they got from agriculture could increase. Despite these challenges, the food and income got by farmers cannot be underrated. Officials reported that uncontrolled agricultural activities degrade the land and pollute the environment. However, urban farmers had opinion that such problems were exaggerated. They gave a pretext reason that adverse effects on environment caused by uncontrolled agricultural activities were exacerbated by limited access to land.

\section{Discussions}

\subsection{The Nature of Urban Agriculture}

The issue of access to land for practising urban agriculture was hotly debated by the respondents. This is because it influences the other variable namely the location of agricultural activities, the types of agriculture and the size of agricultural land. In both Daraja Mbili and Lemala, land was mainly accessed through inheritance and squatting on the restricted public land. Land was inherited by the family or clan members. This situation has resulted to limited access to agricultural land by people who had opportunity to access it through inheritance. Squatting on public land was restricted by bylaws, but it was adopted by farmers who could not get land through inheritance or by purchasing it.

In both wards, the land squatted for urban agriculture was the smallest in size because those who squatted on it were very many compared to the size of the land available. A similar situation was noted in Kampala City where urban farmers who had limited customary access to land had smaller portions of agricultural land. As a result, agricultural activities were done in the restricted areas, which were against environmental conservation (Sabiiti et al., 2014). Inheritance of agricultural land was common in Lemala, but owing to ongoing urbanization and increase in the price of land, part of land was sold to those who were capable of offering a good price and the land was used for residential purposes. This suggests that the size of the land which had been inherited would decline owing to 
the pressing non-non agricultural uses.

On the other hand, the size of such land, which was partly used for carrying out agricultural activities, was larger (more than $2000 \mathrm{~m}^{2}$ ) in Lemala than in the Daraja Mbili. This was due to the fact that Daraja Mbili had a bigger population and closely built residential houses than Lemala. In both Daraja Mbili and Lemala, limited number of farmers who had security of tenure with respect to land which they farmed could and had established permanent infrastructure for carrying out their agricultural and livestock activities. Such farmers also cultivated permanent crops and kept their livestock in enclosed areas closer to where they lived. By contrast, the squatters were regarded as unlawful occupants of the land they invaded. Similarly, Wahab et al. (2018) reported that farmers who did not have the security of tenure in Ibadan City in Nigeria hesitated to grow perennial crops and construct permanent water wells because their occupancy rights over the agricultural land were not certain. The implication of this scenario is that agricultural land tenure influences the location in which agricultural activities take place and the type of agriculture practised in terms of the crops grown and the livestock kept. It could not be possible, for example, for a farmer to build chicken coops or sheds for other types of livestock, or grow permanent crops such as bananas and fruit trees on the land which was not legally occupied. Farmers grew short-term crops like vegetables in the areas located away from where they lived, but vegetable could be not completely relied on as source of food. The farmers squatted on public land cultivated vegetables in small patches of land with very little capital investment because they would lose little if they stopped cultivating the land. In this regard however, no one can confidently say that urban agriculture is adequately promoted when farmers get land by themselves without anyone's help.

\subsection{The Value of Urban Agriculture}

The value of urban agriculture in terms of income and food which urban farmers and those involved in the chain of urban agriculture got was not enough. However, what farmers harvested and earned helped them in terms of optimising their food security and complementing their income. The urban farmers who supplemented their meager income with the little money they got from farming activities were perceived to be creative and better off than those who did not get anything from anywhere else (Kutiwa et al., 2010; Victor et al., 2018). What the urban farmers in Daraja Mbili and Lemala were getting reduced their life hardships.

It should be noted that the amount of income and the level of food security were not the same for all the farmers in Daraja Mbili and Lemala. The variation in their income from urban agricultural activities was compounded by the size of the land, the type of crops they grew or the livestock they kept. A farmer who kept broilers and layers or one who kept pigs or dairy cows was more likely to have a higher income than one who kept limited number of ducks or goats. That 
was because the former were highly consumed and commanded for price. Moreover, the farmer who grew spinach, amaranth, cassava leaves or eggplant got less income than the farmer who grew bananas and leeks or tomato which had a higher market value and which was in high demand in the city.

The value the farmer got was also influenced by the type and size of the land and whether the land was secured or not. In Arusha City, the market for agricultural products was unquestionable and the products were not always sufficient. The study revealed that the livelihoods of farmers in terms of food and income were partly tied to urban agriculture because it is where they eke a living. However, there was a possible decline of agricultural based livelihood in the near future if land use decision makers will not address agricultural land access hurdles. Study by Kutiwa et al. (2010) show that the value of urban agriculture was discussed implicitly in connection to access to land. The land to do agricultural activities is a foremost determinant of its existence (Mireri, 2013).

Unlike the farmers in Lemala, those in Daraja Mbili reported the dwindling of their livelihoods owing to the conversion land into residential plots of the land which had previously been used for agricultural purposes. In turn, this reduced not only size of the agricultural land, but also the types of crops which could be grown or the livestock which could be kept. Moreover, the by-laws against the appropriation of land through squatting had begun to be enforced strictly. This has an implication that even squatting on public land for agricultural activities will be soon be impossible.

Another value of urban agriculture was related to conserving the urban environment in terms of minimizing land degradation or contributing to greening urban areas. Environmental officers at the ward level highly focus on growing of trees and fodder or crops that highly prevent the environment from being degraded. Nonetheless, most of the farmers in both wards also cultivated whatever they found useful to them, especially the crops which they directly consume or could easily sell. As the study reveals, the decision to engage in informal activities such as urban agriculture, which cushioned life hardship of the farmers, is regarded appropriate, but cannot be effective when it is not given a due consideration by authorities responsible for urban land use matters. On the other hand, avoidance of agricultural activities that lead to environmental destruction or pollution has its merits. The protection of the environment and supporting of individuals' livelihoods through agriculture were both important in varying degrees in the areas covered by this study. The farmers rarely bother for environmental protection the way they do with agriculture related livelihoods. This means that, if the environment is not protected; nothing will be preserved for future generations. However, enhancing environmental protection without promoting the informal activities such agriculture which sustain people's livelihoods cannot result into reliable income generation and improve the welfare of the people.

Arguably, agricultural activities that fit in the urban area must deliver the greatest possible benefits in terms of food, income and the environment, while at the 
same time minimising the adverse effects that might be associated with it (Hallett et al., 2016). In Daraja Mbili and Lemala, livestock droppings were used as manure while the crop peels, leaves and food remnants were used to feed livestock. However, that was used in a small scale, it was an endless cycle, which reduced the pollution that otherwise could pollute the environment. Except for green plants which partly come from and were part of urban agriculture, nothing else can make the city look green. Thus, farming for food, income and environmental protection are of vital importance to urbanizing areas whose people are challenged by unemployment and food insecurity.

\subsection{Policy Implications}

The promotion of urban agriculture has to go hand in hand with clarification on how its adverse effects on the urban environment could be minimised. The policy statements on the promotion of urban agriculture become more meaningful when they are supported with financial resources and technical know-how to minimize environmental degradation and pollution without impairing livelihoods of the people. The implementation of a policy on urban land uses and environmental protection should not consider agriculture as only a threat, because despite their negative effects, agricultural activities make a positive contribution to the environmental protection, besides being a source of farmers' livelihoods. The problems it causes to the environment can be managed or minimized. Therefore, a policy relevant to urban agriculture should contain provisions indicating that agricultural activities contribute to the protection of the urban environment, compliment coherent urban development and ensuring livelihoods to those involved in them. That way, stakeholders can devise mechanisms which would lead to the preparation of a well balanced policy on urban agriculture promotion, setting mechanism to address land access hurdles and ensure and environmental protection.

\section{Conclusion and Recommendation}

With regard to the nature of urban agriculture, the study has shown that the practice of urban agriculture is constrained by inadequate access of agricultural land. Former agricultural land is highly converted into non-agricultural uses as a result of ongoing urbanization and population increase in urban areas. Limited access to agricultural land made farmers to find land by themselves, even in the unauthorized areas. The land they illegally acquired was relatively small (400 $1000 \mathrm{~m}^{2}$ ) and did not have security of tenure. Agricultural activities mainly done on the small piece of illegal land, limit their expansion. Farming on restricted public land through squatting on public land was considered illegal, but continued, irrespective of the fines imposed by the ward officials on culprits. It continued because many farmers had limited source of livelihoods. A type of agriculture practised on such land was off plot agriculture which is subject to stealing of agricultural products. The land with unsecured tenure cannot be intensively in- 
vested or planted with permanent crops. With regard to access to land through inheritance for on-plot agriculture, few farmers can have opportunity of inheriting that land from the fore generation. All these jeopardise the prosperity of urban agriculture and impair the livelihoods; the urban farmers could get from it.

The study has found that urban agriculture has somehow contributed to food and income for farmers involved in the production and people engaged in its distribution chain. Although the contribution was not very large, some farmers were better off than farmers who did not have alternative source of food and income. This suggests that the value of urban agriculture for food and income cannot be underrated. Although uncontrolled urban agriculture pollutes and degrades parts of the urban environment, the value of urban agriculture outweighs its adverse effects which could be mitigated by adopting environmentally friendly agricultural practices. It is therefore imperative that city's officials and urban farmers strive to get the best out of urban agriculture while at the same time minimizing its adverse effect. Since agriculture cannot prosper without adequate access to land, ensured access to agricultural land is important. This can be achieved by farmers through temporarily leasing of government or individuals' idle land or through implementing the land use plans that incorporating agricultural land. Agricultural activities that conserve or protect the environment to a greater extent should be greatly supported through sustainable agricultural programmes and related agricultural extension services. Without addressing agricultural hurdles related to land, farmers' livelihoods condition will be weakened. Moreover, underrating agricultural adverse effects to the environment will further impair environment at great extent.

\section{Conflicts of Interest}

The authors declare no conflicts of interest regarding the publication of this paper.

\section{References}

Arusha City Master Plan Draft Report (ACCMPDR) (2015). http://www.arushacc.go.tz

Aubry, C., Ramamonjisoa, J., Dabat, M. H., Rakotoarisoa, J., Rakotondraibe, J., \& Rabeharisoa, L. (2012). Urban Agriculture and Land Use in Cities: An Approach with the Multi-Functionality and Sustainability Concepts in the Case of Antananarivo (Madagascar). Land Use Policy, 29, 429-439. https://doi.org/10.1016/j.landusepol.2011.08.009

Badami, M. G., \& Ramankutty, N. (2015). Urban Agriculture and Food Security: A Critique Based on an Assessment of Urban Land Constraints. Global Food Security, 4, 815. https://doi.org/10.1016/j.gfs.2014.10.003

Barofsky, J., Siba, E., \& Grabinsky, J. (2016). Can Rapid Urbanization in Africa Reduce Poverty? Causes, Opportunities, and Policy Recommendations. Brookings Institute. Africa in Focus.

Crush, J. S., \& Frayne, G. B. (2011). Urban Food Insecurity and the New International Food Security Agenda. Development Southern Africa, 28, 527-544.

https://doi.org/10.1080/0376835X.2011.605571 
Dorward, C., Schutzbank, M., \& Mullinix, K. (2013). The Economics of Urban Farming. In The Urban Farming Guidebook: Planning for the Business of Growing Food in BC's Towns and Cities (pp. 37-44). EcoDesign Resource Society. http://www.kora.kpu.ca

Game, I., \& Primus, R. (2015). GSDR 2015 Brief Urban Agriculture. State University of New York College of Forestry and Environmental Science.

Hallett, S., Hoagland, L., Toner, E., Gradziel, T. M., Mitchell, C. A., \& Whipkey, A. L. (2016). Urban Agriculture: Environmental, Economic, and Social Perspectives. In J. Janick (Ed.), Horticultural Reviews (Vol. 44, pp. 65-120). Wiley-Blackwell. https://doi.org/10.1002/9781119281269.ch2

Hamisi, R. (2012). Contribution of Urban Agriculture to Food Security: A Case Study of Sombetini, Daraja Mbili, and Sokoni One Wards, in Arusha City. University of Dar es Salaam School of Law.

Kiduanga, J., \& Shomari, A. (2017). Urban Agriculture: Critical Issues of Land Administration for Expansion of the Farming of Vegetables in Dar es Salaam. Journal of the Geographical Association of Tanzania, 36, 115-134.

Kombe, W. J. (2005). Land Use Dynamics in Peri-Urban Areas and Their Implications on the Urban Growth and Form: The Case of Dar es Salaam, Tanzania. Habitat International, 29, 113-135. https://doi.org/10.1016/S0197-3975(03)00076-6

Kutiwa, S., Boon, E., \& Devuyst, D. (2010). Urban Agriculture in Low-Income Households of Harare: An Adaptive Response to Economic Crisis. Journal of Human Ecology, 32, 8596. https://doi.org/10.1080/09709274.2010.11906325

Lau, H. L. (2013). Evolution of Urban Agriculture in Hong Kong: Stepping Towards Multifunctionality. Doctoral Dissertation, Chinese University of Hong Kong. http://www.academia.edu

McLees, L. (2011). Access to Land for Urban Farming in Dar es Salaam, Tanzania: Histories, Benefits and Insecure Tenure. The Journal of Modern African Studies, 49, 601-624. https://doi.org/10.1017/S0022278X11000498

Mireri, P. C. (2013). Assessment of the Contribution of Urban Agriculture to Employment, Income and Food security in Kenya: A Case of Kisumu Municipality. African Journal of Agricultural Research, 8, 2884-2896.

Mkwela, H. S. (2013). Urban Agriculture in Dar es Salaam: A Dream or Reality? WIT Transactions on Ecology and the Environment, 173, 161-172.

Mougeot, L. J. (2000). Urban Agriculture: Definition, Presence, Potentials and Risks. Growing Cities, Growing Food: Urban Agriculture on the Policy Agenda, 1, 42.

Mugisa, I. O., Fungo, B., Adur, S. O., Semalulu, O., Molly, A., Atim, J., \& Akello, B. O. (2017). Urban and Peri-Urban Crop Farming in Central Uganda: Characteristics, Constraints and Opportunities for Household Food Security and Income. African Journal of Plant Science, 11, 264-275. https://doi.org/10.5897/AJPS2016.1477

Namwata, B. M., Kikula, I. S., \& Kopoka, P. A. (2015). Access of Urban Farmers to Land, Water and Inputs for Urban Agriculture in Dodoma Municipality, Tanzania. Journal of African studies and Development, 7, 31-40.

Odudu, C. O., \& Omirin, M. M. (2012). Evaluating the Constraints Affecting Land Access among Urban Crop Farmers in Metropolitan Lagos. Journal of Agribusiness in Developing and Emerging Economies, 2, 130-146.

https://doi.org/10.1108/20440831211272599

Peters, K. A. (2010). Creating a Sustainable Urban Agriculture Revolution. Journal of Environmental Law and Litigation, 25, 203-247. 
Quan, J. (2015). Family Farming and Land Governance: Towards a People-Centred Approach: Synthesis of Findings of a Research Project Supported by the International Land Coalition. Annual World Bank Conference on Land and Poverty, 1, 48.

Sabiiti, E. N., Katongole, C. B., Katuromunda, S., Sengendo, H., Basalirwa, C. P., Atukunda, G., \& Nambuubi, S. K. (2014). Assessing Urban and Peri-Urban Agriculture in Kampala, Uganda. In J. Padhgam, \& J. Jabbour (Eds.), Building Urban Resilience. United Nations Environment Programme.

Sarker, A. H., Bornman, J. F., \& Marinova, D. A. (2019). Framework for Integrating Agriculture in Urban Sustainability in Australia. Urban Science, 3, Article No. 50. https://doi.org/10.3390/urbansci3020050

Schmidt, S. (2012). Getting the Policy Right: Urban Agriculture in Dar es Salaam, Tanzania. International Development Planning Review, 34, 129-145. https://doi.org/10.3828/idpr.2012.9

Smit, W. (2016). Urban Governance and Urban Food Systems in Africa: Examining the Linkages. Cities, 58, 80-86. https://doi.org/10.1016/j.cities.2016.05.001

Tefft, J., Jonasova, M., Adjao, R., \& Morgan, A. (2017). Food Systems for an Urbanizing World. World Bank. https://doi.org/10.1596/32502

Un-Habitat (2008). State of the World's Cities 2008/9: Harmonious Cities. UN-Habitat.

United Republic of Tanzania (URT) (2000). National Human Settlements Development Policy. The Ministry of Lands, Housing and Human Settlements Development, Tanzania.

United Republic of Tanzania (URT) (2007). Urban Planning Act, 2007. Government Printer.

Victor, K., Massawe, F. A., \& Sikira, A. (2018). Contribution of Integrated Urban Agriculture to Household Income: A Case of Kinondoni Municipality, Tanzania. Journal of Agricultural Sciences -Sri Lanka, 13, 237-246. http://doi.org/10.4038/jas.v13i3.8397

Wahab, B., Popoola, A., \& Magidimisha, H. (2018). Access to Urban Agricultural Land in Ibadan, Nigeria. Planning Malaysia, 16, 161-175.

Wakuru, M. (2008). Improving Urban Land Governance with Emphasize of Integration of Urban Agriculture Based Livelihoods in Spatial Land Use Planning Practices in Tanzania. Doctoral Thesis, Albert-Ludwigs-Universität.

World Bank (2013). Urban Agriculture: Findings from Four City Case Studies. https://www.worldbank.org/

Yang, Z., Hao, P., Liu, W., \& Cai, J. (2016). Peri-Urban Agricultural Development in Beijing: Varied Forms, Innovative Practices and Policy Implications. Habitat International, 56, 222-234. https://doi.org/10.1016/j.habitatint.2016.06.004 